(9) (1) $\mathrm{https://creativecommons.org/licenses/by/4.0/}$

LEARNING RHYTHMIZED BY CHILDREN: Drumming at Olho do Tempo Living School in João Pessoa, Paraíba, Brazil

\author{
Karla Jeniffer Rodrigues Mendonça ${ }^{1}$ \\ http://orcid.org/0000-0002-5875-8813 \\ Flávia Ferreira Pires ${ }^{2}$ \\ http://orcid.org/0000-0003-0572-3542
}

\begin{abstract}
This study analyses the relationships of childhood learning in the educational context of the Olho do Tempo Living School, a civil society organization of public interest located in a rural area of João Pessoa in the Brazilian state of Paraíba, where children engage in the practice of drumming as a pedagogical proposal. We weave together interdisciplinary theories on early childhood learning and learning through practice. From a patchwork based on participant observation of the children's actions and perceptions, we address the following categories that both were felt and emerged in the fieldwork: participation, autonomy, development and growth in/with the body. We conclude that the actions understood by the children as "learning on one's own" and "holding one's own" are entangled with conflicting ties (re)born in intra- and intergenerational relations and in relations with things (mainly the instruments) in the environment. It is through these relations that the children deconstruct the adultcentric interpretation of the teaching-learning relationship.
\end{abstract}

Keywords: children, learning, drumming, intra- and intergenerational relations, João Pessoa

\title{
AS APRENDIZAGENS RITMADAS PELAS CRIANÇAS: Batucando na Escola Viva Olho do Tempo (João Pessoa, PB)
}

RESUMO: Este artigo tem como objeto analisar as relações de aprendizagem na infância no contexto educacional da Escola Viva Olho do Tempo (EVOT), uma Organização da Sociedade Civil de Interesse Público localizada na área rural de João Pessoa, Paraíba, no qual as crianças se envolvem na prática do batuque como proposta pedagógica. Para isso enlaçamos, de forma interdisciplinar, teorias que tratam da aprendizagem na infância e da aprendizagem na prática. Nesse emaranhado, baseadas em uma observação participante e atentas às ações e percepções das crianças, tratamos categorias sentidas e emergidas na pesquisa de campo: participação, autonomia, desenvolvimento e crescimento no/com o corpo. Concluimos que as ações entendidas pelas crianças que implicam "aprender sozinho" e "se garantir" se misturam aos vínculos conflituosos (re) nascidos nas relações intra e intergeracionais e com as coisas (sobretudo os instrumentos) no ambiente. São nessas relações que as crianças desconstroem a noção adultocêntrica associada à relação ensinar-aprender.

Palavras-chave: crianças, aprendizagem, batuque, relações intra e intergeracionais, João Pessoa.

\section{APRENDIZAJE APRENDIDO POR NIÑOS: \\ Batucada en Escola Viva Olho do Tempo (João Pessoa, PB)}

\footnotetext{
${ }^{1}$ Universidade Federal da Paraíba (UFPB).João Pessoa, PB, Brasil. < karla-pessoa@hotmail.com>

${ }^{2}$ Universidade Federal da Paraíba (UFPB). João Pessoa, PB, Brasil. < ffp23279@gmail.com >
} 
RESÚMEN: Este artículo tiene como objetivo analizar las relaciones de aprendizaje en la infancia en el contexto educativo de la Escuela Viva Olho do Tempo (EVOT), una organización de interés público de la sociedad civil ubicada en la zona rural de João Pessoa, Paraíba, en la que los niños son implican la práctica de la percussión (batucada) como una propuesta pedagógica. Para esto, vinculamos, de manera interdisciplinaria, las teorías que tratan sobre el aprendizaje en la infancia y el aprendizaje en la práctica. En este enredo, basado en la observación participante y atento a las acciones y percepciones de los niños, tratamos las categorías sentidas y surgidas en la investigación de campo: participación, autonomía, desarrollo y crecimiento en / con el cuerpo. Concluimos que las acciones entendidas por los niños que implican "aprender solo" y "garantizar" se mezclan con los lazos conflictivos (re) nacidos en las relaciones intra e intergeneracionales y con las cosas (especialmente los instrumentos) en el entorno. Es en estas relaciones que los niños deconstruyen la noción centrada en el adulto asociada con la relación de enseñanza-aprendizaje.

Palabras clave: : niños y niñas, aprendizaje, batucada, relaciones intra e intergeneracionales, João Pessoa.

\section{INTRODUCTION}

This article originated as a chapter of a dissertation titled "To the beat of the drums: Knowledge rhythmized in childhood at the Olho do Tempo Living School ${ }^{3}$ (No tempo dos tambores: Os saberes ritmados pela infância na Escola Viva Olho do Tempo)" defended it in 2018 in the Federal University of Paraíba's Graduate Programme in Sociology. The research focused on childhood learning as participatory action in collective practice, was conducted at the Olho do Tempo Living School (Escola Viva Olho do Tempo - EVOT), located in the Gramame neighbourhood, a rural area on the outskirts of João Pessoa, the capital city of the Brazilian state of Paraíba.

In this article, we discuss and analyse learning relations, highlighting how the children who participate in the "Drums of Time" group in percussion workshops understand the practice of drumming in the school environment and in presentations in public and private spaces. We emphasize how the children learn, how they drive their own learning in the group and how they engage in rehearsals and situations managed by adults, focusing on intra- and intergenerational relations in the rehearsals and in other daily experiences through which the children share knowledge. We adopt an interdisciplinary approach that draws on studies of childhood and theories on learning through practice and identify categories including participation, development/growth/time and autonomy based on know-how with regard to knowledge and the skills (in)corporated in/with practice (INGOLD, 2010; LAVE, 2015; CORSARO, 2011; TOREN, 2012).

We invite you, the reader, to enjoy the children's drumming, and if you can hold your own, feel free to join.

\section{SETTING AND METHODS}

The study was conducted in the Gramame neighbourhood, located in the greater metropolitan area of João Pessoa, a setting characterized by numerous socioeconomic disadvantages. In this setting, children are typically sent at a young age to institutions responsible for their education, protection and care; thus, the children are cast in the role of student and trainee in the submissive and adult-centric sense (TASSINARI, 2009; QVORTRUP, 2014).

\footnotetext{
${ }^{3}$ This dissertation considered childhood learning as participatory action in the environment of the Olho do Tempo Living School. It sought to understand and analyse how the children perceived and managed their experiences. In this context, it was possible to observe how the children's autonomous actions emerged through their relations with the people and things in their educational environment, thus highlighting the children's engagement in collective practices, particularly with/in drumming. The study participants were children aged 5 to 17 years, along with the educators and collaborators who performed and participated in the school's daily activities and projects.
} 
At EVOT, however, we interacted with approximately 120 children aged six to sixteen years ${ }^{4}$ who attend the institution outside of school hours to engage in educational practices based on griot, popular and holistic pedagogies ${ }^{5}$. The school links workshops on literacy, arts, technology and the environment to a pedagogical practice based on oral traditions and sociopolitical engagement conceived as an educational campaign; in this way, the school strives for a recognition and an appreciation of the community as a cultural and historical environment (SOUZA, 2014; TOLENTINO, 2016).

This study focuses on understanding the children in their learning experiences based on and through their own perceptions as learners on a life trajectory by considering the intertwining of their paths, stories and social relations with the things (INGOLD, 2012) and people around them. The research path developed through daily involvement with the children in the activities and practices that interested them. The directions of the analyses in this ethnographic study emerged through drawings the children gave to the researcher, through the children's invitations to join in their games, through inclusion in their conversations and particularly through involvement in the practice of drumming. The children were the main mediators and "controllers" of the collection of data presented here. We sought to preserve spontaneity before inviting them to dialogue with us or tell their stories, as well as in our observations of them and engagement in their practices and experiences.

We valued the children's role as co-researchers (CHRISTENSEN; JAMES, 2005) within a methodological process in which participant observation succeeds only through the formation of bonds and engagement with the children's practices. As Christensen and James (2005) emphasize:

\begin{abstract}
Researchers therefore do not necessarily have to adapt different methods but rather adapt practices related to the interest and routines of children [...] to better understand childhood and represent a faithful image of the children's daily lives, we must be able to explore through our methodologies what is common and what is different in their social experience through time and space (CHRISTENSEN; 2005, p.19, author's italics).
\end{abstract}

Our research approach is not concerned with trying to understand children by age groups. Rather, it asks whether and how particular ages within the same generation affect the practice of drumming and the institution's environments, particularly in the absence of adults.

Personal involvement in daily activities was indispensable. The researcher's role in the institution was recognized, and the children also expressed curiosity and interest in knowing what the researcher was planning to "do" with them, as they observed her observing them, temporarily suspending the potential hierarchy in the adult-child relationship and building a bond based on trust through open engagement to understand the process of experiential learning.

Among the daily activities and experiences observed by the researcher, highlights included the conversation groups in the Acacia theatre initiated by the educators ${ }^{6}$ and the children, the "storytelling sessions" under the cashew tree that drew on the history and memories related to life in the neighbourhood and EVOT, participation in the twice-weekly percussion workshops, watching the rehearsals of the Drums of Time group and their performances in various places and participating in school celebrations featuring the children's music and dancing.

As an adult, the researcher understood the learning relationships, conflicts and transformations and how the children incorporated knowledge with respect to their historical, social, economic and cultural conditions when she felt, in and with her body, the movements made by the

\footnotetext{
4 The category "children" is adopted based on the self-identification of the group studied. The participants are involved in and convene for practices in which they see themselves as having common interests and experiences.

${ }^{5}$ EVOT's pedagogical proposal incorporates concepts that arise from these pedagogies, presenting a collection of practices that are based on the discourse of: "shared management", "engagement", “empowerment", "dreams", "games", "masters", "group" and "play" (MENDONÇA, 2018; SOUZA, 2014; SHOR; FREIRE, 1987).

${ }^{6}$ The social educators of EVOT, most of whom reside in the neighbourhood, work according to a social and collective proposal based on shared management, which extends to their relations with the children. They engage in educational, administrative, political and artistic activities in the school and share responsibility with the children for workshops on technology, sociocultural, artistic and environmental activities. On the activity of educators at EVOT, see Mendonça (2018) and Igor Souza (2014).
} 
children as they learned to drum. However, her understanding was superficial and lacked the same quality of perception the children mentioned when commenting on the practice.

In addition to these perceptions and analyses of lived experience, three semi-structured interviews were conducted with the children (as a group) with the educators' consent but without their presence. The groups formed spontaneously as the children paired off, typically based on affinity and friendship. Characterized as group discussions, the interviews generally ended up being led by the children as they sought to "explain" how and what they learn by drumming at EVOT. They seemed to be motivated to reveal the power they acquired by becoming "knowledgeable" about the knowledge (re)born in the simultaneous relationship with the educator, other children and the instruments.

Through a dynamic process and by listening to the children, we learned how to question them and therefore how to better understand them. We learned not only through their verbalized comments but also by listening to the sound they produced with their bodies as they simulated drumming with their hands and legs and drummed on the tables with the objects around them during the interviews.

This article includes photographs taken by the children as well as a drawing. These artefacts, along with photographs taken by the institution's media director and available on the social network that we selected in cooperation with some children in the computer workshops, were fundamental to understanding their perceptions of the practice of drumming. Importantly, these visual data accompanied the children's explanations of the recorded context, reporting on their own and others' actions, perceptions of the environment and the successes and disappointments experienced in a given moment.

The data analysis is accompanied by an interdisciplinary analysis focusing on childhood studies, which considers experience in the present and values childhood memories. Thus, we focus initially on the discussion of learning relationships in/with practice and time of/for learning, identifying theoretical considerations related to studies of childhood and learning that support our field observations. We then discuss how the children understand and manage their actions in the process of learning shared knowledge by stating that they learn to drum "on their own." Next, we address the knowledge incorporated and successfully presented in practice by the children and their potential for new productions by "showing off" and "holding their own" in the drumming. Lastly, we address some notions and dialogues that emerged through involvement with the children in the drumming practice, as we share how, in this social field, the children learn, share and incorporate their knowledge.

\section{“IN TIME": LEARNING THROUGH AND FROM PRACTICE}

Time appears in this study not only in relation to the name of the percussion group, which refers to the name of the school, but also as a dynamic category associated with generations, with lived experience, with play time and institutional times, with arrival and departure times, with what is early and what cannot be left for later and particularly with time for learning, for (re)doing and (re)inventing. We understand that through a dynamic process in childhood, learning paths are woven and (re)created through continuous modification and growth in collective environments, which are (in)corporated in the world of socialized knowledge.

We follow Prout (2010, p. 746) in recognizing the study of childhood as part of the study of the life course, as the "analysis of the life course is a broad topic, which includes historical time (generations and cohorts), individual time (life history and biography) and institutional time (sequences and transitions)". It is in this patchwork, woven during and over time, that generations dialogue and understand knowledge and ways of acting with it in context. However, in the case of learning during the life course, learning time appears to be associated with children, whereas teaching time is associated with adults. Notably, these times are presented differently in the field, as we clarify throughout this article.

Knowledge and thus social practices seem to be couched in terms of evolution, particularly with regard to the chronological time of life. From a perspective within developmental psychology, age is often the organizing principle of when and how one learns (CASTRO, 2013): the greater the knowledge, the longer one has lived, the more stages have been completed. If a child demonstrates a skill considered innate or surprisingly advanced for a young age due to its complexity, this accomplishment immediately evokes surprise: it is too early to have such knowledge, or the child is gifted. 
As part of this discussion, Sirota (2007) notes that scientific movements that aim to measure children's performance according to a universal standard also spur social and educational movements that value precociousness as a qualitative measure of childhood learning; thus, individuals who do not master age-appropriate abilities are overlooked or excluded.

Given that children are considered dependent and are institutionalized at a young age, how can they be recognized as agents of knowledge with creative skills? Christina Toren (2012) writes:

A new-born, baby or small child needs other human beings to take care of its basic needs, making its ontogeny a social process $[. .$.$] The propensity to understand the surrounding world is a crucial$ aspect of human beings. It follows that learning is a dynamic spatiotemporal process that, at each point, inevitably places human beings historically in relation to other beings, in specific places and moments of time in the world in which they live (TOREN, 2012, p. 22).

When asked during interviews how early one can start learning to drum and how long the process requires, most children answered that there is no minimum age to learn and "start drumming," as older and younger children generally learn quickly, showing proudly how they learned what they currently know at an early age. For example, Mikellayne (age 7), looking around at the various instruments in the room, says, "I know how to play the drum, agbê (gourd rattle), ganzá (Brazilian rattle), and I learned all of this when I was five years old". Rian (age 8) recounts that he learned at the age of 6 but explains that these days, he makes mistakes and forgets the music, lamenting, "Because I told my mother to take me out of school, I used to be a strong player, but now... (he simulates drumming with pencils, demonstrating by his acting that he no longer has the same skill with the instruments he used to have)" (conversation group, May 2017).

Drumming requires ongoing rehearsals and regular practice and is therefore grounded in real-world experience. During breaks in the rehearsals of the Drums of Time group, the children explain that their skills are based on knowledge acquired during their practice at EVOT and is linked to their ages, actions and environment. They say that they "learn a bunch of stuff, like how to play the drum and agbê and dance, because we've been here a long time" (Paola, age 8, and Parla, age 7, conversation group, May 2017).

Trust and empathy among participants in this process is also considered crucial for those with know-how, who, as they analyse the learning process and engagement of others, share this knowledge "over time".

I teach them everything, and they know who they're gonna teach. I taught them something, and they should only teach someone who is on their wing and wants to learn, but it takes time, and I see the children sometimes asking how to do this or that, and they say, "I'm not telling!" And they don't tell, and if you go ask Bruno (age 11), who knows the most, he won't tell; he just says, "You'll learn later." (Percussion teacher and Director of the Drums of Time group, interviewed on 17 August 2017).

By getting involved and "showing they really want to learn" (conversation group with the children, 2017), the children assert themselves as active and vulnerable participants in this context, while keeping pace with each other in relation to the rhythm and ways they are learning. Consequently, although they understand these relationships are shaped by the subordination of the child who has yet to absorb the knowledge to the one who has mastered it, the children nonetheless seem to understand learning as part of the dynamic flux of living, as their experiences (re)blossom in the patchwork of relations, demonstrating the deconstruction of the position of the adult (teacher) as the main source of learning. This idea is discussed further in the next section. As Paola (age 8) explains:

There are people who didn't even know how to hold the drumstick, like me. I kept watching. I learned by watching and doing it. I started playing well, and my brother started saying, "Look, Paola can play!" Nobody taught us; we learn by listening to the others singing, and then we repeat it. (Paola, age 8). (Field log, 2017).

With regard to learning knowledge that is socially and culturally practised in the environment, such as learning to walk or play an instrument or a sport, Ingold (1999) states that this development occurs through interaction among people and things; culture is not a package of information that can be genetically inherited or simply transmitted. Thus, he emphasizes that it is not humans' abilities that enable them to participate in learning but rather abilities (re)formed through practical action in an environment, 
whose neurological connections and corporeal features are gently combined so that these systems are generators and regenerators of the learned skills and not rigid.

At many of the Drums of Time performances, we observed that adults in the audience remarked with almost universal surprise on the children's ability to "play like adults," which, of course, they attributed to the teacher's teaching skill. This response may indicate how "age remains a socially constructed field where power differences, struggles over meaning, sentiments and fictionality influence the definition of when a certain age begins and what it means" (CASTRO, 2013, p.27).

The children are aware of these comments at their performances. Adult-centred spaces view these children as "out of the ordinary," and one child even objects to this way of seeing them, commenting, "you just have to want to, and you'll learn," meaning age and generation are not the determining factors of mastering skills. Thus, the children emphasize how early they were able to learn an instrument or even several instruments simultaneously, simply by being willing to learn. They offer an example of two children, ages 7 and 8, who "should already have learned", given the amount of time they have been involved in the practice, but whose lack of effort has prevented them from learning.

Christina Toren (2012) argues that physical and moral makeup is the dynamic product of a biosocial history. She explains that rather than being solely a brain function, each human being's mind is a function that emerges fully through intersubjective relations with those in the environment. Within this discussion, Tim Ingold (1999) acknowledges that the link between human nature and culture can be established only through the "human mind." He bases this reasoning on Mauss's argument that actions assimilated or imitated by individuals are conditioned by a set of three inseparable elements: the biological, the social and the psychological, of which the last is the "gear" for the processes through which the body adapts to its use. He emphasizes, however, that it is insufficient "to combine the biology of human nature with the sociology of cultural difference to produce a complete 'biosocial account'."

We consider the children's statements important when they say the time required to learn varies with the student's willingness to learn. As they also emphasize, effort and engagement is required by all those involved, meaning not simply the student but everyone and everything, thereby establishing a contract so that knowledge can be shared and understood among the teacher, the children, the school (environment) and even the instruments.

Thus, considering the complexity of the learning process, including the environmental, biological, social, historical and psychological factors involved in this process, we can emphasize the dynamic action that occurs in the body, as it moves and transforms itself in the world through dialogue between the past and present. The time presented here as age, bonds among those with more experience and the practices incorporated over the life course prompt reflections that revolve around how the children in the Drums of Time group understand the learning process and how we perceive them in this process.

Accordingly, over the course of the study, learning came to be understood as growth that occurs relatively autonomously in the sense of developing and acquiring know-how in the practical context of drumming and other experiences (re)born through these relations. In the following section, we discuss how autonomy and participation are understood as categories observed in the children as they show how they learn drumming through experience.

\section{“I LEARNED ON MY OWN"}

Doing, practice, participation and experiences are actions that permeate the discussions related to childhood learning, whether in psychology, pedagogy, anthropology or sociology. Reflecting on this process with the children practising drumming at EVOT in mind, we suggest here that learning is related to a type of growth that is possible only through exposure and physical engagement in complex actions that involve thinking, emotions and technical movements in the course of interactions and affective contracts with humans and objects in the environment. We consider this suggestion next, as we highlight the children's actions during their experience of learning in an educational context that connects formal and informal knowledge through musical practice.

The research process in this study, which also entailed a learning process as we followed the children's perceptions of learning/drumming, highlights their awareness of their bodily work in this 
practice, ensuring, through a dialogical, sensitive and reflective process, their perception, based on their particular circumstances, of how they master or do not master their performances.

The rehearsals or workshops herein, cited as moments in which the children and the educator, or 'teacher', as they call him, experience the practice together, entail movements and bodily relations in which orality, observation and the perception of actions occur among the children, as the process of learning and teaching includes everyone. However, the children considered that learning and mastering skills appeared to occur independently, i.e., through daily attempts at self-improvement (NUNES, 2003; QUEIROZ, 2016).

Each day, when they observed the researcher watching them play, particularly before the rehearsals, the children eagerly sought to exhibit a new beat or skill they had learned, and whenever possible, they were asked to explain what they were playing and how they had acquired this skill. Under these circumstances, the expected answer was that the teacher had taught them-this setting was, after all, a school, but they surprised the researcher by answering, "I learned it on my own."

In explaining that they had learned to drum on their own, the children associated their perceptions with the actions performed by/through their own bodies. Moreover, when they insisted that "to learn, you just have to want to," we can argue that this sentiment arises from the relationships of delight that children experience when drumming, namely, by promoting pleasurable experiences of participating in a group, (re)empowering themselves in the act of playing, singing, dancing and having new experiences that take them beyond their typical daily routines. On the understanding of participation as comprising attentive engagement in the practice of drumming, we concur with Marilia Stein (2009):

Everyone, each with his or her own degree and type of ability and experience, should feel comfortable enough to play his or her part, while at the same time stimulated by the challenge of overcoming their limits, learning new skills, creating new or more elaborate possibilities of interaction through sound and movement. Participatory musical practices are usually open, with no pre-established beginning, middle or end. (STEIN, 2009, p. 68).

At EVOT, the child's first contact with an instrument is typically by choice at the beginning of a workshop, as if, at the first encounter, the child were open to being seduced by the instruments' different sounds, shapes and sizes. Arranged on the floor of the Acacia theatre, the instruments (drums, agbes, gonguê bells, ganzás and caixa drums) aroused the curiosity of the arriving children, who wanted to touch them but knew they could only be played with the permission of the teacher or one of the children assigned to the task.

The workshops typically begin with a conversation circle in which the teacher starts by describing what the children will experience and matters related to the daily routine of the EVOT. The children wait eagerly for the moment they can handle the instruments and use them to create the sound that sets everyone in the school to swaying and "makes the heart beat stronger" (field journal, 2017). The teacher then advises the younger (less experienced) children to follow the example of the older ones, specifically observing how they position their arms and legs, how they hold the instruments and how they move. At times, the teacher himself stood next to a child and guided the child through a movement that may have been out of synch or helped the child join in the cadence of a more advanced drummer.

The workshops usually occurred in small groups by instrument and sometimes involved the children all playing together. The EVOT has both before- and after-school sessions, and the Drums of Time group has approximately 70 children.

After the instruments are chosen and are in position, the drumming starts at the sound of the whistle and command of the teacher, who stands and signals with his hands, indicating the rhythm the drumming will take. Given the large number of participants of different ages and backgrounds, involvement and physical performance assume different forms, notwithstanding the unity of the sound. Each child displays performative actions that reflect their particular story, related not only to how they learned or learn their instruments but also to how they act in the group, how they transform it and are transformed by it. According to the one child:

I'm still learnin' to play the drum, you have to keep watching, you have to sway your body (then the children stand up and act out in gestures how the body should move, imitating the sound of 
the drums), and then you also have to always keep your eye on the teacher because he'll blow the whistle to signal when it's time to go boom, boom... (Damião, age 11).

While the children were playing, we noticed that some children, particularly the younger ones, were hanging back, playing games in the corners or simply sitting on the stage to watch the drumming. Nonetheless, it was apparent that they were not completely detached from the vibe of their surroundings, as they were singing along, swaying slightly, dancing hesitantly or drumming on the floor with their hands.

We observed that one girl, who typically participated in the percussion workshops, did not engage at the same time as the other children, even with the teacher's encouragement. She sat at the edges of the group, watching, playing or reading comic books, or, as she told me, "looking at" comic books, as she could not read. She revealed that she thought the playing was very noisy and that what she really liked was dancing maracatú style, singing and even playing the agbê, but she kept her distance when older children with "more skills" approached, withdrawing shyly because she considers herself a novice. When explaining her actions with regard to drumming, she concluded that what she really enjoyed was putting away the drums and drumsticks at the end of the rehearsal.

Such adjustments that children make to their daily practice depending on the context reaffirm an autonomy whereby they adapt to feel comfortable, and this understanding is arguably valid even when they are accompanied by the teacher. The anthropologist Ângela Nunes (2003) describes this adaptation in her study of the daily lives of Xavante children and their participation in the traditional educational contexts of their ethnic group and the schooling environment. Through her observation of and interaction with the children, Nunes formed the sense that despite exhibiting different skill levels, the children remained open to the unexpected, to playfulness and improvisation in the practices permeated by a fusion of school activities and the culture, as she observed that their "eyes would shine and their bodies, vibrate" (NUNES, 2003, p. 287).

Some children assume a leading role in this teaching and learning relationship, likely due to their greater experience (time) and practical skill. Relations of trust form as the children seek partners to explain certain movements they do not fully understand. The partners may even offer to help children experiencing greater difficulty if they feel qualified to do so. The children's autonomy is apparent on these occasions in that they seek to organize themselves to learn or even to sing or play their songs freely, even in the teacher's absence, because "you have to watch to learn (which another child confirms)...we love this! You have to watch, listen to the sound!" (Diogo, age 10). We understand autonomy in the sense used by Montandon and Longchamp (2007, p. 108), who recognize "a person's ability and power to govern themselves, to make decisions that concern them... a person is capable of being autonomous when they are aware of this reality."

Whenever the researcher was invited to play the drum during the workshops, the children drew close to demonstrate how to hold the drumstick and start the beat. At that moment, it was apparent that they intended to help the researcher feel comfortable and attentive to the movements. Furthermore, everyone paid attention to seeing and hearing each other with their instruments, as it was the teacher's guidance and the children's acceptance and inclusion that made everyone responsible for the group's performance, particularly considering the large number of participants.

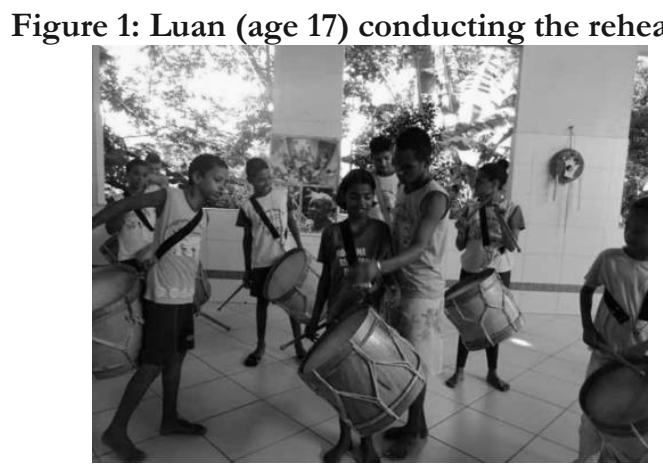

Source: First author. 
This sensitivity suggests being (re)born in the experience of the sound, a type of (re)created communication that aims for harmony in the group, requiring everyone to understand and follow the rules of this game. It is this process of educating attention (INGOLD, 2010) that makes the children present and participants in the process: "You have to watch, pay attention, close attention, to be able to learn. I play the drum, I'm doing everything the teacher says, and I watch my friends.” (Naiane, age 6). (Field log, April to August 2017).

The children emphasize that many attempts are required to "get the groove," that is, learn the beat, which demands physical engagement in which one observes, watches, listens to the sound and does. Learning the beat requires successive experiences based on what is "shown" (INGOLD, 2010), based on the "bonds" established with the agents (human or non-human) and through intersubjective mediation among those experiencing childhood, who are endowed with agency, traversing a dynamic path in which they learn to register and be sensitive to the world (LATOUR, 2008). Following Tim Ingold's concept of "enskillment" (2000), we argue that these skills arise through practical understanding, as the result of the movements the children perform with their bodies in achieving mastery of the instruments, accompanying their more experienced peers.

Through drumming, the body is transformed, which, for the children, means "getting the hang of it," or playing, dancing, singing and smiling simultaneously, indicating that "the children learn by doing, in the concreteness of the act" (PIRES, 2011, p. 175). This patchwork of actions can only emerge in relation to the other, who holds the knowledge to be understood, such as the teacher and the other children who are more skilled due to their longer experience of practice. This developmental process is what the children clarify by reporting that they "do everything they say to do," suggesting that notions of authority and trust are born of these understandings, in the weaving of relations.

As Emilene Sousa (2017, p.3) observes with regard to peasant societies, "learning for children is the same as know-how, as it is for the adults or older siblings who serve as their reference." Analogously, the children who are learning to drum form bonds with others who "know how" and can share the necessary knowledge, thus not relying only on guidance from adults.

"Catching on" in this context also appears to refer to an intrinsic ability that is moreover specific to each person, as the children perform at different levels and do not necessarily "acquire" knowledge in a controlled way, for instance, at the same pace and at the same time. At times, one of the younger girls, Andressa (7 years), refused to participate in the percussion workshops and performances with the Drums of Time group, but on other occasions, she participated in the rehearsals and demonstrated skill with her body and instrument (agbê) similar to the movements the researcher had seen among women who play in the maracatú groups and nations in Recife. Her highly unusual dexterity and fluidity of movement prompted the researcher's interest in knowing how she had learned, and the emphatic response was, “That's just her!". According to the teachers, the dance teacher did not teach her because even she noted that she could not dance like Andressa. Similarly, in her study of children's daily experience of candomblé religious centres, Stela Guedes Caputo (2012) was surprised when a four-yearold boy, Ricardo, explained his role as ogan (drummer) at the centre. Curious, the researcher asked how he had learned to play for the Òrisà (gods), and he replied, "I learned by watching"; the centre's mãe-desanto (priestess) added that no one had taught him to drum, that "it's an ancestral gesture."

Through music, the children enact a social agreement and perform affectionate exchanges among themselves and in partnership with the teacher and other involved adults in/through that which unites them in public. From this participative and interdependent performance is born a spell woven by the socializing practice of music. 
Figure 2: Naiane's drawing (age 6): "When we play, we are heroes and heroines".

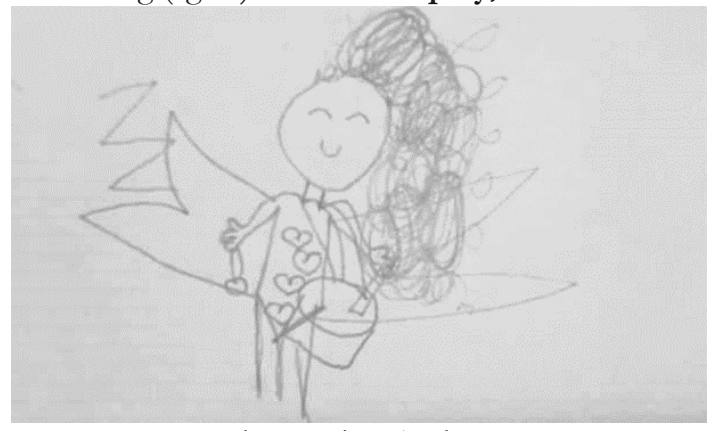

Photo: First Author

Therefore, the power incorporated through successful drumming practice can be understood as an act of "self-empowerment" (SHOR; FREIRE, 1987), as the children show a desire and willingness to participate in drumming at EVOT as a way of being present and appropriating the symbolic goods and exchanges that are (re)born in the school: day trips to the city and its surroundings, games played at celebrations and performances and access to new ideas and people in the cultural context of João Pessoa.

Amid the smiles, laughs and squabbles, these experiences facilitate animated exchanges of meanings that are uncommon in the children's daily lives. For them, participating in a social group that sees itself as "empowered" by skills and involved with elements that convey emotions, in this case, music and dance, promotes a "new conception of the world" by demonstrating a "unique way of living the collective, of perceiving the world and relating to it" (PEREZ, 2014, p.187). We discuss these emotions (re)born of drumming knowledge next.

\section{“HOLDING ONE'S OWN"}

When observing the Drums of Time group playing at its performances, we recognized that despite tiredness or occasional stumbles, the learning (re)unites the group in pursuing a common end, which is a good performance. Nervousness and tension characterize the rehearsals and the minutes before the performances, starting with the whistle that the teacher (drum master) uses to call the children's attention to his directions, particularly with regard to the songs they will play and the specific movements to be executed.

The children appear apprehensive at these moments, particularly the most experienced members, because these moment are when the most skilled, experienced and developed members are recognized and assigned to sing at the microphone and play the most complex rhythms, such as turns and transition passages. Under these circumstances, many children vie to perform the most elaborately, but they cannot always be included because, based on their performance during the workshops, the teacher considers that they require more time/training. When denied, the children often argued, trying to change the teacher's mind; sometimes they were successful and managed to be chosen, while other times, they had to submit to the adult's authority and knowledge.

Based on these initial agreements, the whistle signals, gestures and facial and physical expressions during the drumming are crucial to the success of the collective performance. During the apparently successful Drums of Time shows ${ }^{7}$, mistakes appeared as acts to be reconsidered or cause for the children to demonstrate persistence, feel anxiety or even quit. In the children's view, mistakes are unavoidable in the learning process. They consider that despite momentary frustrations, as children, they can err with fewer and less serious consequences than can adults. It was possible to feel this attitude when, after a researcher had felt shy about her awkward movements in an exercise, which revealed a certain amount of shyness when executed in the group, Ana Parla (7 years old) looked at her and, noticing that the researcher was insecure and withdrawn, said, "I also make mistakes sometimes!".

Assuming greater responsibility in the drum group, the older children (in age and experience) indicate that when the teacher or children in leadership roles identify an error, they worry and lose their

7 To watch the performance of the children in the "Drums of Time" group at the Olho do Tempo Living School, see: https://www.facebook.com/escolavivaolhodotempo/videos 
concentration even more, mainly because they feel they are not "fixing" the issue or not "holding their own." "Holding one's own" means feeling secure and confident based on others' assessment of one's performance. Chantal Medats (2014) also observed this notion in the participants in her study: those who cannot "hold their own" must observe the actions for a longer period, until they can "guarantee" that they are able to participate. This process improved their ability to observe so that they could "see more and see better."

According to the children, mistakes often result from a lack of engagement with the instruments and the group. Dissonant sounds prompt correction by the child's peers because when someone does not "hold their own," meaning they are insecure and commit mistakes frequently, they disturb others' concentration and attention. Arguments can also emerge when one child notes another's mistake or does not accept responsibility for causing the group's mistake. Such conflicts disturb the group's harmony and require an intervening word or action to (re)synchronize the group; this intervention can come from the teacher or from younger or older children in the group.

The children state that in the process of gaining know-how, some of them may become "show-offs," that is, demonstrate their "practical understanding" (LAVE apud INGOLD, 2000) in a performance, displaying a power that has been incorporated and made visible to others. In this regard, noting that the body is a human being's primary instrument as an individual, Mauss (2003 [1935]) emphasizes that each act occurs in response to another individual, whether an adult or child, who assimilates the movements of the actions they witness or engage in, in an imitative, or rather educational, process. Discussing the concept of habitus, Mauss (2003 [1935]) recognizes the body in the world as an agent that transforms and is transformed, considering that children are different from other generations in adapting their bodies to the socially disseminated physical techniques, viewing successful acts as prestigious.

However, among the successful actions in drumming, the children distinguish between actions that are performed with confidence and those that, in their view, do not indicate conscious control, that is, indicate a failure to "hold their own." From their perspective, the children involved in the group "only show off a little because show-offs play hard, and in the Drums of Time, we play with fluidity; it's fluidity with the arms and legs. You use your head to think about everything the teacher is saying" (field journal, 2017). Thus, they emphasize that "showing off" is acceptable when it occurs in a happy, engaged and successful manner, that is, with precision and without mistakes.

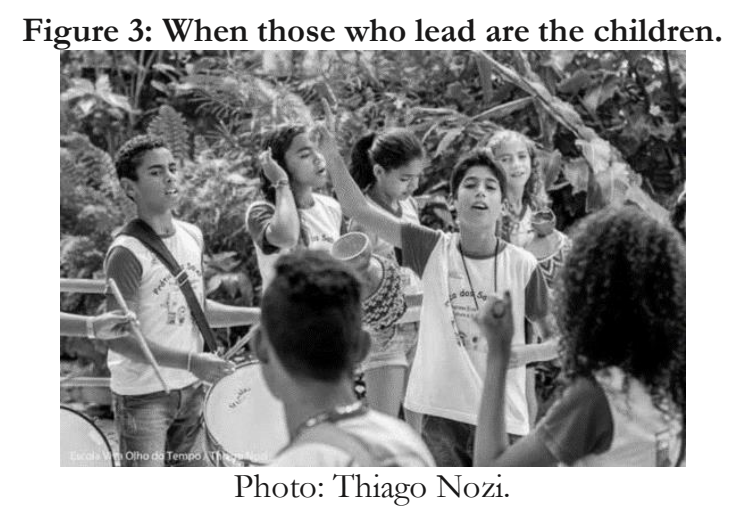

Considering that "a performance takes place as an action, interaction and relation" (Schechner, 2006, p. 31), we argue that the children's drumming performance shows an "increased awareness" (INGOLD, 2000) that derives from communication with others and practical physical involvement in the world. What exists are feelings that do not react in a manner suspended in action but that define the group as a patchwork woven from imagination, perception and intentionality, which is receptive to transformation and creativity.

The dynamic produced by and with the children's actions in their performances was a mixture of restless bodies provoked by the vibrations of the instruments that conveyed curiosities and experiences, possibly unfelt before, to the audience in a lively and imaginative manner. The children did not like when the drumming seemed "listless," that is, dull and inharmonious with the surrounding festive atmosphere; at these moments, the teacher and other children encouraged them to cheer up, using 
creative and unexpected actions and improvised shouts, twirling and dancing. During these moments, the children, as mentioned, sought to show that they could "hold their own," involving the entire group in mutual trust, attentive to the emotions their performance was producing in the audience.

The drumming actions performed by the children are complex movements that involve the entire body through guided (re)discoveries (INGOLD, 2010), that is, in what they feel and experience in inter- and intragenerational relations, particularly with the instruments and the songs born of the relation between the two. The movements are active and embodied learning experiences in the sense that the corporeality only emerges as a perception in the form of presence and involvement in the world, with the body as the source of existence and the location of experience (CSORDAS, 2008, p.102).

Knowledge of practice results from the actions that the children take with the body in mastering the instruments, where this mastery, in Lave's view (1996, 2015), occurs through sharing actions among the people and objects involved and is characterized by the organization and unity of these relations in practice.

In her analysis of learning with/in practice, Jean Lave (2015) notes that learning and knowledge emerge through relations, as "things are constituted by, and constituted as, their relations; thus cultural production is learning, which is cultural production" (LAVE, 2015, p. 40, authors' italics). In this educational process, thinking about childhood and learning relationships produce memories related to gestures, collectively lived experiences and techniques embodied by physical, intellectual and emotional effort. Thus, what lives in drumming today derives from an embodied memory that will be part of the course of the children's lives and become part of their stories.

We observe that drumming practice (re)creates the bodies of these children, not only in the sense of understanding the movements and development of skills but also in the appearance of feelings and emotions, while immersed in hierarchies that are recognized and that guide them in the techniques of imitation and repetition. In drumming rehearsals to "get the hang of it" and "hold one's own", learning cannot blossom without feeling knowledge. These conditions indicate reciprocity and openness to feel what comes from the pleasures and knowledge produced by oneself and by/with others.

In these multiple, conflicting relations between learning and "holding one's own" discussed in this section, we reflect on how meanings are experienced and produced in different ways by the children through attentive actions of being present in the collective act of drumming, and thus "showing off," revealing movements in which the practice is acquired by the children in mastering their actions, without necessarily becoming dependent on or controlled by adults.

\section{CONCLUSION}

By observing the children in their practice of drumming, this study discusses and rethinks learning relations in childhood, seeking to understand through/with the children how one learns to drum through/in intra- and intergenerational relations in the setting of the Olho do Tempo Living School. By observing the context of practice and the incorporation of knowledge experienced and perceived by the children through their bodies, we analysed the movements that emerge through relations of bonding and trust among them and the others involved (the adults and instruments) and reflected on insights that were intriguing in terms of childhood learning.

In the children's view, knowledge is directly related to not age but rather the time devoted to understanding and becoming skilled at the practice, as drumming knowledge is exhibited in practice at each rehearsal and performance. Thus, anyone who is willing, engaged and attentive to the guidance offered by more experienced drummers (the teacher and other children) and to the feelings (re)born in each movement of seeing, hearing, feeling and playing, can learn.

While, given the institutional context, emphasizing that the teacher bears the knowledge and responsibility for leading the group activity, the children also note that merely being present in the environment and exposed to this knowledge is not the determining factor for learning and that the role of the adult in this relationship, as has been stated, is not the sine qua non for learning. Thus, by arguing that transmitting is not teaching, we also underscore that learning only occurs by doing in a complex cognitive, practical and historic process that emerges from these experiences. During the drumming, hierarchies change, compete and (re)position themselves, creating a mixture of perceptions in which the 
children develop their movements in such a way that they develop their desire to demonstrate newly incorporated knowledge, that is, they "get the groove," not in the cumulative sense but as a social process through which they are transformed and become agile.

Among the synchronized and harmonized movements in sharing knowledge and the display of success in practice, the children's actions can be considered relatively autonomous not only because their experiences suggest that each person's willingness is crucial to learning to drum and "holding one's own" but also because the children, in and through their bodies, leave themselves open to the transformations and relationships that the instruments and the intra- and intergenerational relations provoke in the environment. In this emotional bond, in the contract with everything and everyone, knowledge is (re)born and occurs among the mistakes and successes and even in alleged momentary disinterest. The children seek to (re)skill themselves in the new, in the satisfaction that results from showing oneself empowered through a knowledge (re)blooming in the collective.

The practice of drumming involves the children in actions in which their bodies are exposed to sensations, changes and mastery at each rehearsal: at each performance, an inseparably emotional and physical process occurs through the blend of feeling and being present, despite conflicts and frustrations that arise daily. In these analyses, we understand that each body responds differently to the process of learning in/with/through practice.

Our understanding is that each child's learning process emerges in being (re)born and developing in the body through/with mentoring and movements guided and engaged with other people and objects. We understand that this learning can "hold its own" by being an inspired, open and attentive movement along a path that undergoes a relational process of imagination, perception, (re)flourishing skills, understanding and creativity/improvisation.

\section{REFERENCES}

CAPUTO, Stela Guedes Caputo. Educação nos terreiros e como a escola se relaciona com crianças de candomblé. 1.ed. Rio de Janeiro: Pallas, 2012.

CASTRO, Lucia Rabello de. O futuro da infância: os impasses nas relações intergeracionais e das crianças com seus pares. In: . O futuro da infância e outros escritos. 1. ed. Rio de Janeiro: 7 Letras, 2013. p. 3784.

CHRISTENSEN, Pia; JAMES, Allison (orgs). Investigaçoes com crianças: perspectivas e práticas. Tradução Mário Cruz. Porto: Edições Escola Superior de Educação de Paula Frassinetti, 2005.

CORSARO, William A. Sociologia da Infância. Tradução Lia Gabriele Regius Reis. Porto Alegre: Artmed, 2011.

CSORDAS, Thomas. A Corporeidade como um Paradigma para a Antropologia. In: Corpo, significado, cura. Porto Alegre: UFRGS, 2008. p. 101-146.

INGOLD, Tim. Three in one: on dissolving the distinctions between body, mind and culture. Department of Social Anthropology. University of Manchester. Oxford Road. England, 1999. Available in: <http://lchc.ucsd.edu/mca/Paper/ingold/ingold2.htm>. Accessed on 04/07/2017

The poetics of tool use: from technology, language and intelligence to craft, song and imagination. In: . The Perception of the environment: essays on livelihood, dwelling and skill. London: Routledge, 2000. p. 406-419.

. Trazendo as coisas de volta à vida: Emaranhados criativos num mundo de materiais. Horizontes Antropológicos, Porto Alegre, ano 18, n. 37, p. 25-44, jan./jun. 2012.

. Da transmissão de representações à educação da atenção. Educação, Porto Alegre, v. 33, n. 1, p. 6-25, jan./abr. 2010.

LATOUR, Bruno. Como falar do corpo? A dimensão normativa dos estudos sobre a ciência. A dimensão normativa dos estudos sobre a ciência. In: NUNES, J. A.; ROQUE, R. (Org.). Objetos impuros: experiências em estudos sociais da ciência. Porto: Afrontamento, 2008. p. 40-61. 
LAVE, Jean; WENGER, Etienne. Situated learning: legitimate peripheral participation. Cambridge: Cambridge University Press, 1996.

LAVE, Jean. Aprendizagem como/na prática. Horizontes Antropológicos, Porto Alegre, ano 21, n. 44, p. $37-$ 47, 2015. Avaiable in: <http://www.scielo.br/pdf/ha/v21n44/0104-7183-ha-21-44-0037.pdf>. Accessed on: 05/08/2017.

MAUSS, Marcel. As técnicas do corpo. In: Sociologia e antropologia. São Paulo: Cosac \& Naify, 2003[1935]. p. 399-422.

MEDAETS, Chantal. “Tu garante?”: Transmission and Learning Practices Along the Tapajós River. Childhoods Today, Volume 8, Issue 1, 2014. Available in: <http://www.childhoodstoday.org/article.php?id=78>. Accessed on 04/01/2018.

MENDONÇA, Karla Jennifer Rodrigues de. No tempo dos tambores: Os saberes ritmados pela infancia na Escola Viva Olho do Tempo. Dissertation. (Master Degree in Sociology) - Universidade Federal da Paraíba, Paraíba, 2018.

MONTANDON, Cleópâtre; LONGCHAMP, Philippe. Você disse autonomia? Uma breve percepção da experiência das crianças. Perspectiva, Florianópolis, v. 25, n. 1, p. 105-126, abr. 2007. Available in: <https://periodicos.ufsc.br/index.php/perspectiva/article/view/1631>. Accessed on: 15/11/2017.

NUNES, Ângela. "Brincando de ser criança": contribuições da Etnologia Indígena Brasileira à Antropologia da Infância. Thesis (PhD in Antropology). Instituto Superior de Ciências do Trabalho e da Empresa, Lisboa, 2003.

PEREZ, Léa Freitas. Alguma [mínima] teoria e um pouco de his[e]stória. In: PEREZ, Léa Freitas; MARTINS, Marcos da Costa; GOMES, Rafael Barros (orgs). Variações sobre o reinado: um rosário de experiências em louvor a Maria. Porto Alegre: Medianiz, 2014. p. 177-195.

OLHO DO TEMPO. ESCOLA VIVA. Facebook. Disponível em: <https://www.facebook.com/olhodotempoescolaviva/videos>. Acesso em: 20/10/2018.

PIRES, Flávia Ferreira. Quem tem medo do mal assombro? Religião e infância no semiárido nordestino. Rio de Janeiro: E-papers; João Pessoa: UFPB, 2011.

PROUT, Alan. Reconsiderando a nova sociologia da infância. Tradução de Fatima Murad. Cadernos de Pesquisa, v.4, n.141,2010. p. 729-750

QUEIROZ, Poliana Jacqueline Oliveira. "Bora agitar?!”: as crianças na dança dos mascarados de PoconéMT. Dissertação. Mestrado em Antropologia Social. Cuiabá: Universidade Federal de Mato Grosso, 2016.

QVORTRUP, Jens. Visibilidades das crianças e da infância. Tradução: Bruna Breda. Revisão técnica de Maria Letícia Barros Pedroso Nascimento. Linhas Críticas, Brasília, DF, v. 20, n. 41, p. 23-42, 2014. Available in: <http://periodicos.unb.br/index.php/linhascriticas/article/view/9308/7743>. Accessed on: $21 / 05 / 2017$.

SCHECHNER, Richard. “O que é performance?”. In: . Performance studies: an introduction. 2. ed. New York \& London: Routledge, 2006. p. 28-51.

SHOR, Ira; FREIRE, Paulo. Medo e Ousadia: o cotidiano do professor. Tradução de Adriana Lopez; revisão técnica de Lólio Lourenço de Oliveira. Coleção Educação e Comunicação, v. 18. Rio de Janeiro: Paz e Terra, 1986.

SIROTA, Régine. A indeterminação das fronteiras da idade. PERSPECTIVA, Florianópolis, v. 25, n. 1, jan./jun. 2007, p.41-56.

SOUSA, Emilene. Umbigos enterrados: corpo, pessoa e identidade Capuxu através da infância. Florianópolis: Editora UFSC, 2017. 
SOUZA, Igor Alexander Nascimento de. Na confluência da roda: Educação Patrimonial, Diversidade Cultural e a Pedagogia Griô. Dissertation (Master Degree in Preservação do Patrimônio Cultural). Rio de Janeiro: Instituto do Patrimônio Histórico e Artístico Nacional, 2014.

STEIN, Marília Raquel Albornoz. Kyringüé mboraí - os cantos das crianças e a cosmo-sônica Mbyá-Guarani.Thesis. (PhD in Music). Porto Alegre, Universidade Federal do Rio Grande do Sul, 2009.

TASSINARI, Antonella. Múltiplas Infâncias: o que a criança indígena pode ensinar para quem já foi à escola ou A Sociedade contra a Escola. Anais online. Caxambu: ANPOCS, 2009. Available in: $<$ http://anpocs.com/index.php/encontros/papers/33-encontro-anual-daanpocs/gt-28/gt16-24/1935antonellatassinari-multiplas/file>. Accessed on: 15/03/2017.

TOLENTINO, Átila Bezerra. Espaços que suscitam sonhos: Narrativas de memórias e identidades do Museu Comunitário da Escola Viva Olho do Tempo. (Master Degree in Sociology). João Pessoa: Universidade Federal da Paraíba, 2016.

TOREN, Christina. Antropologia e psicologia. Revista Brasileira de Ciências Sociais, Caxambu, vol. 27, $\mathrm{n}^{\circ}$ $80,2012$.

Submetido: $20 / 10 / 2018$

Aprovado: 06/05/2019 